\title{
Circuit
}

Musiques contemporaines

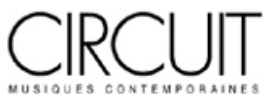

\section{Rethinking Automatist Interdisciplinarity: The Relationship between Dance and Music in the Early Choreographic Works of Jeanne Renaud and Françoise Sullivan, 1948-1950 Repenser l'interdisciplinarité automatiste : le rapport entre la danse et la musique dans les premières oeuvres chorégraphiques de Jeanne Renaud et Françoise Sullivan, 1948-1950}

\author{
Allana C. Lindgren
}

Volume 21, numéro 3, 2011

Musique automatiste ? Pierre Mercure et le Refus global

URI : https://id.erudit.org/iderudit/1006359ar

DOI : https://doi.org/10.7202/1006359ar

Aller au sommaire du numéro

Éditeur(s)

Les Presses de l’Université de Montréal

ISSN

1183-1693 (imprimé)

1488-9692 (numérique)

Découvrir la revue

Citer cet article

Lindgren, A. C. (2011). Rethinking Automatist Interdisciplinarity: The Relationship between Dance and Music in the Early Choreographic Works of Jeanne Renaud and Françoise Sullivan, 1948-1950. Circuit, 21(3), 39-53. https://doi.org/10.7202/1006359ar
Résumé de l'article

Cet article évalue le rôle de la musique dans le contexte des automatistes de Montréal en se penchant sur les oeuvres chorégraphiques créées par Jeanne Renaud et Françoise Sullivan au cours de la fin des années 1940 et du début des années 1950. Il apparaît dès lors que les activités autour de la danse de ces deux chorégraphes évoluent souvent en parallèle avec des expériences contemporaines en musique. Les collaborations de Renaud et Sullivan avec Pierre Mercure étaient particulièrement réussies, et démontrent en fin de compte que la musique constituait une partie importante de l'histoire des automatistes, même si Mercure n'était pas signataire du manifeste automatiste, le Refus global. 


\title{
Rethinking Automatist Interdisciplinarity:
}

\section{The Relationship between Dance} and Music in the Early Choreographic Works of Jeanne Renaud and

\section{Françoise Sullivan, 1948-1950 ${ }^{1}$}

\author{
Allana C. Lindgren
}

\section{"Seeing and hearing no longer need to be considered separately..." \\ - Michael Nyman ${ }^{2}$}

The interdisciplinary activities of the Montréal Automatists are well-documented. 3 Paul-Émile Borduas, the leader of the group, was a painter whose progressive ideas about the arts and society attracted a wide range of creative young followers during the 1940s and 1950s. Some, though not all, were visual arts students at the École du meuble de Montréal where Borduas taught. The interests of many of these young artists extended beyond painting to include dance, theatre, literature, design and photography. In general, all were aesthetically inspired by the spontaneity of the Surrealists, with leanings to abstraction in painting, eager to explore their creative potential unhampered by preconceived ideas or self-censorship, and politically agitated by the conservative political and religious authorities that wielded power in Québec at the time. 4 They gathered in each other's homes for lectures and art exhibitions. They collaborated on dance performances, theatrical productions, and the publication of poetry accompanied by illustrations. Their impassioned
1. I would like to acknowledge Miriam Adams and Amy Bowring at Dance Collection Danse as well as Drs. Ray Ellenwood and Claudine Caron for their kind assistance during the preparation of this article. I am particularly grateful to Jeanne Renaud and Françoise Sullivan for their ongoing generosity. Merci.

On the topic of this article, see also Bourrassa and Lapointe, 1988 and Lapointe, 2009.

2. Nyman, 1974, p. 19.

3. For example, see Ellenwood, 1987, p. 11-27; Ellenwood, 1992; Ellenwood [1985] 2009; Gagnon, 1998; Nasgaard and Ellenwood, 2009; Smart, 1998.

4. Like the Surrealists, Borduas and his protégés were attracted to the liberating ideological and aesthetic potential of spontaneity without selfcensure and to the use of automatism as a means to access the subconscious. One of the main differences between French Surrealism and Québécois Automatism was that the artists associated with the latter preferred to pursue non-figuration in their work. 
5. For more about the photographs documenting the Automatists and the artist who was the de facto photographer for the group, see Perron, 1999 debates about ideology and modernist aesthetics, fueled by a keen desire to revitalize their society, became works of art as captured in the photographs documenting their activities through the years. ${ }^{5}$

However, the one art form that has received scant scholarly attention within the context of the Automatists, is music. To begin to remedy this situation, this article suggests that music was a critical component of the early dance concerts organized by Jeanne Renaud and Françoise Sullivan, two of the Automatists interested in choreography. Specifically, a discussion of the close relationship between musical and dance elements in two choreographic works these women premiered at a recital in 1948 demonstrates the fissures between standard Automatist precepts and dance, and suggests that the early choreography of Renaud and Sullivan is better illuminated within the historical and analytical frameworks of music. Secondly, Pierre Mercure, as young Québec composer associated with the Automatists, was the first contemporary musician to collaborate with Renaud and Sullivan. These collaborations occurred early in the careers of all three, and their significance both for Mercure and for the choreographic development of Renaud and Sullivan is worth considering. Moreover, the critical response to Mercure's compositions for Sullivan's choreography, particularly for three works he created for her in 1949, can be viewed as fostering a public dialogue about contemporary music and modern dance in Montréal. Finally, Mercure's working method when composing for Renaud in 1950 for a dance concert that the choreographer organized while living in Paris serves as a reminder that Automatist performance practices were aligned with and informed by experimentation in music.

Although this article only addresses three dance concerts spanning the years 1948 to 1950, it should be noted that the first Automatist dance recital presented jointly by Renaud and Sullivan took place in the summer of 1946 . Unfortunately, a lack of archival evidence makes it difficult to evaluate the musical significance of this event beyond noting that Moi je suis de cette race rouge et épaisse qui frôle les éruptions volcaniques et les cratères en mouvement, a piece that the two women co-choreographed, was accompanied by the recitation of a poem of the same name written by Renaud's sister, Thérèse.

Similarly, it needs to be acknowledged that Mercure's collaboration with the Automatists did not end with the 1950 Paris performances. On the contrary, during the 196os, Mercure wrote the music for several choreographic works created by his partner, Françoise Riopelle, another member of the Automatists who was involved in dance. While the relationship of Mercure's intriguing experimental electronic compositions to Riopelle's avant garde 
choreography deserves more scholarly attention, it is beyond the scope of this paper which deals essentially with the interface between dance and music within the period of greatest Automatist activity just prior to and immediately following the 1948 publication of the group's manifesto, Refus global.

The manifesto is arguably the reason why music has largely been overlooked in the history of the Automatists. In the late 1940s, the Automatists were preparing for an exhibition of abstract paintings and wanted to create a catalogue to accompany the images. The exhibition was set aside as the group chose to focus on the catalogue which soon morphed into a manifesto of nine texts articulating the group's beliefs. Mercure had been a potential signatory to the manifesto and apparently had participated in the discussions prior to the publication of Refus global although, according to Automatist Claude Gauvreau several years later, the composer ultimately did not sign because he felt the manifesto was too incendiary. ${ }^{6}$ Gauvreau's comments, however, might be biased because in 1949 the two men had a public and rather fractious disagreement over an opera they had planned to create together. JeanPaul Mousseau presented a different theory in 1972. According to Mousseau, Mercure initially did not agree with his Automatist colleagues because he felt that taking a philosophical, social or political stand "was a lot of bull-shit for an artist...". 7 However, Mousseau also believed that Mercure later recalibrated his views to more closely align with the Automatists' ideals. ${ }^{8}$ Indeed, Mercure acknowledged the influence of Automatism on his work, stating in 1961, "J'aimais entendre ces gens discuter. J'essayais de trouver en musique ce que ces individus avaient trouvé en peinture et en littérature." " For whatever reason Mercure's name does not appear on Refus global, his absence meant that none of the manifesto's sixteen signatories were musicians. ${ }^{10}$

Before they began their productive collaborations with Mercure, both Renaud and Sullivan were restless with the dance community in Montréal and both headed to New York to expand their understanding of choreography. Renaud, whose sisters Louise and Thérèse both signed Refus global, had always been passionate about music and dance. ${ }^{11}$ Her mother, who passed away when Renaud was a child, had played the piano and often listened to recordings of music by Gabriel Fauré, Reynaldo Hahn, Erik Satie, Claude Debussy, Maurice Ravel, Sergei Prokofiev, Dmitri Shostakovitch. This love was passed on to her children and the Renaud home was filled with music throughout her formative years. ${ }^{12}$ As a child, Renaud also took piano lessons, studied classical ballet with Gérald Crevier and later modern dance classes with Elizabeth Leese. When she followed her sister Louise to New York, Renaud opted to study primarily at the Hanya Holm studio with such
6. The assertion that Mercure was involved in the discussions about Refus global is presented in Laplante, 1976, p. 4. For more information about Gauvreau's thoughts about why Mercure did not sign Refus global, see Ellenwood, 1992, p. 208-209; and Gagnon, 1998, p. 482.

7. Jean-Paul Mousseau, 1972, as freely translated by Lyse Richer-Lortie in Lefebvre and Richer-Lortie, 1976, p. 11

8. I would like to thank Dr. Claudine Caron for bringing Compositeurs au Québec to my attention and for her informative email discussion with me on Mercure's decision not to sign Refus global.

9. Pierre Mercure in Lefebvre and Richer-Lortie, 1976, p. 11.

10. The signatories to Refus global were Paul-Émile Borduas, Magdeleine Arbour, Marcel Barbeau, Bruno Cormier, Claude Gauvreau, Pierre Gauvreau, Muriel Guilbault, Marcelle Ferron, Fernand Leduc, Thérèse Renaud-Leduc, Jean-Paul Mousseau, Maurice Perron, Louise Renaud, Françoise Riopelle, Jean-Paul Riopelle and Françoise Sullivan. Automatist scholar Ray Ellenwood believes that the women who were part of the Automatists, along with Claude Gauvreau, were more attuned to musical innovation than most of the other male members of the group. Ellenwood has theorized that the absence of a consideration of music in Refus global reflects the lack of knowledge about the discipline by the majority of the group's male writers. I would like to thank Dr. Ellenwood for sharing his views with me (Ray Ellenwood, email to author, November 5, 2010).

11. For more information about Renaud's early life, see Lindgren and Ellenwood, 2009. Also see, Ellenwood, 2006, p. 16-22.

12. Jeanne Renaud in conversation with Ray Ellenwood (Ellenwood, email to author, April 13, 2011). 
13. For more information about Sullivan's life and early career, see Lindgren, 2003; Lindgren, 2005; and Vigneault, 2002.

14. Bettis, 1979, p. 18-53. teachers as Mary Anthony. She liked Anthony's structured technique classes which helped her to physicalize her innovative movement phrases.

Sullivan met Borduas in 1941 and immediately became interested in his visionary ideas. ${ }^{13}$ She had been studying painting at the École des beauxarts de Montréal but soon became one of the young artists who regularly met with Borduas. In 1945, Sullivan decided to further her training in dance which, like painting, she had studied since childhood. She moved to New York for the next year and a half, spending most of her time at the studio of Franziska Boas, the daughter of the esteemed anthropologist, Franz Boas. At the Boas School of Dance, Sullivan was exposed to new ideas about dance composition that Boas had adapted from the Ausdruckstanz training she had received as one of the first students to study at the New York Wigman School during the 1930s. Rather than focusing on the acquisition of technical virtuosity obtained by reshaping the body according to a set syllabus, Boas's pedagogy emphasized the development of each student's individual creativity. This approach freed Sullivan from her preconceived ideas about movement composition so that when she returned to Montréal in the spring of 1947, she was in a phase of intense choreographic creativity that had begun in New York.

In New York, both Renaud and Sullivan were exposed to more than the latest ideas in dance. Both experienced avant garde concepts that crossed artistic disciplines, including music. For instance, Boas was known in the New York dance community for her talent as a percussion accompanist. She was also an avid collector of percussion instruments from around the world which she brought to her studio for students to play, and her penchant for experimenting with the percussion possibilities of non-musical instruments meant that she frequented local junk shops seeking new sounds. In the early 1940s, John Cage taught at Boas's studio and the two would experiment together. The choreographer and dancer Valerie Bettis, who had been a student of Boas's at the time, was struck by the sound innovations conducted at the studio : "I can remember John with Francesca [sic] and myself playing around with the instruments and putting the gong in buckets of water." 14 This ethos of exploration was still present when Sullivan arrived a few years later, although Cage was no longer at the Boas studio. Moreover, both Renaud and Sullivan also spent time with the composer Morton Feldman during their New York sojourns. Renaud, in particular, attended music concerts, visited museums and met other artists through her association with Feldman. To a certain extent Mercure was also a part of Renaud's musical education in New York. He would periodically visit her because they were dating at the time. 
Their conversations continually and passionately circled back to the artistic experimentation Renaud and Sullivan were experiencing. ${ }^{15}$

\section{The Corporeal Score: Bodies and Breath as Music}

On April 3, 1948, Renaud and Sullivan both appeared in Récital de danse - a joint dance concert, which they held at Ross House on Peel Street in Montréal. The two women included choreographic works performed to recorded music, including Renaud's Un monsieur me suit dans la rue, set to an Édith Piaf song, and Sullivan's Black and Tan Fantasy, which she had created to Duke Ellington's song of the same name. The most innovative works, however - Sullivan's Dédale and Renaud's Déformité - were performed in silence, or more accurately, without any traditional musical accompaniment.

Although neither Dédale nor Déformité were notated at the time of the 1948 "Récital de danse," in 1986, Sullivan and Renaud worked with a group of dance artists as part of the Encore! Encore! project organized by Dance Collection Danse Archives in Toronto to reconstruct several Canadian choreographic works. While dance reconstructions must always be approached with caution, the resulting dance "texts" provide insight into Sullivan and Renaud's thinking at the time of creation. For instance, the reconstructed version of Sullivan's Dédale begins with the dancer, dressed in a simple leotard and skirt, on stage facing the audience. Slowly and almost imperceptibly, she closes her hand into a fist and starts to curl and release her wrist. Each time this small movement is repeated it increases in speed and intensity until the dancer is swinging her arm back and forth with such force that it thrusts her entire body from the spot where she has been standing and into a series of movements that flow back and forth across the stage. The body is seemingly caught in impetus of its own swing motion, which slows and swells over and over again. Her neck swings. Her torso swings. Both arms swing violently. At the mid-point of the dance, the dancer, who has been thrown to the floor by her own propulsion, pauses for a moment. The only movement, her ribs heaving with exertion; the only sound, her laboured breath. Slowly and almost imperceptibly, she closes her hand into a fist. Her wrist begins to curl and release into another series of repetitions that build in force again until it picks the dancer up off the floor, and her oscillating rhythm rocks and pivots her through space once again. The dancer ends near where she started. She raises her hand by her head, lifts them up and then extends them in slow motion towards the audience.

Unlike Dédale, which was an exploration of the swing rhythm, the reconstructed version of Renaud's Déformité was the kinetic abstraction of an
15. Telephone interview with Jeanne Renaud, October 30, 2010. In the same interview, Renaud claimed that Mercure had been musically "conservative" while they were dating. She was interested in electronic music, for instance, while he was still under the influence of Igor Stravinsky. 
16. Françoise Sullivan in Hill, 1988, p. C1.

17. Françoise Sullivan in Robert, 1973, p. 270. These comments are also cited in Gosselin, 1981, p. 41.

18. For instance, see Ellenwood, 1992, p. 194. autobiographical event. During her time in New York, Renaud had observed urban deprivation for the first time. Her alarm and distress at seeing poverty so close reached a crisis point the day she was crossing the Brooklyn Bridge and saw a homeless man on a bench. He was dead and his stiff hand was slightly extended as if reaching up towards her. Déformité became Renaud's response to (and outlet for) the anxiety caused by this grisly discovery. The work begins with the dancer wandering tentatively onto the stage. Slowly she rises onto demi-pointe as she arches her back. Suddenly, she begins to pace in staccato steps until she looks down. A shocked expression crosses her face. Her hands slowly rise to cradle her face. While still on demi-pointe, her torso and neck arch back in slow motion before her waist collapses as if grabbed and her hands twist her head side to side in silent agony. Doubled over, the dancer begins to walk in a circle, her arms swinging freely and her spine uncurls to a standing position, one vertebra at a time. As she circles again, the dancer's movements increase in speed and soon she is running in a wide circle, one arm trailing behind. Along her path, she turns without breaking the rhythm and runs backwards for a few steps as if checking to see if someone is behind her. Knowing the background to the dance, it is easy to imagine that the dancer has just seen and is fleeing the dead man. It is enticing to focus simply on the relationship of the movement to the supposed narrative underpinning it. Yet, as the dance progresses, the movements become increasing unfettered from anything resembling a linear story as the dancer appears to give herself over to an unseen force. Her hands pull her hair and her body in one direction and then another. As in Dédale, the dancer in Déformité swings in one direction and then is propelled in another. The urgency of her movements might still be in reaction to Renaud's experience in New York, but the movement is effective on its own because the urgency is conveyed solely through the choreography's violent rhythms.

Forty years after "Récital de danse", Sullivan stated that, through the choreographic works she created in 1948, "I was trying to translate into dance the ideal of the Automatists. I was forming my own language and thoughts about dance." ${ }^{6}$ More specifically, she has stated that in Dédale, she wanted to embody Automatist tenets as "(Je) laisse agir le hasard objectif, les pulsions, les rencontres non préméditées, d'imprévisibles relations et une recherche du mouvement simple, élémentaire, parfois inusité." ${ }^{17}$ Indeed, Dédale does not have a narrative and therefore has been viewed as successfully transposing the Automatist penchant for abstraction or non-figuration to dance. ${ }^{18}$ Similarly, although Déformité is based on a real incident, it too modulates movement away from narrative. 
Yet the connection to Automatist theory is problematic. The body can never truly escape figuration because it is always marked by gender, race, age and so on, and thus is always actively engaged in representation. Moreover, the spontaneity so valued by the Automatists is also difficult to assign to works like Dédale and Déformité, which might have been created extemporaneously (though the highly structured choreography of both suggests otherwise) but, like other modernist dance works of the time, both were set and polished as works to be repeated exactly the same way during each performance.

For these reasons, a more useful approach is to examine Dédale and Déformité in relation to music. In the absence of traditional musical accompaniment, these works can be seen as visual music. The dancers' heads, torsos and limbs physicalize rhythm and emphasize bodies' inherent musicality. (In so doing, they evoke the pedagogy of Émile Jaques-Dalcroze's Eurhythmics training and the long history of embodied musicality.) Furthermore, just as the early-twentieth-century dance theorist Rudolf von Laban noted the connection between movement efforts and emotion, Dédale and Déformité can be viewed as exploring how emotion is initiated through movement. In the 1940s, Sullivan, in particular, was interested in the relationship between rhythm and emotion. She expounded on her thoughts about rhythm in her essay La danse et l'espoir, which was one of the texts in Refus global. In her essay, Sullivan suggests that dancers carefully study how to use rhythm to connect with audiences because "rhythms are among our most efficient forces of communication." ${ }^{19}$ In these ways, Renaud and Sullivan show that music and dance are comprised of the same basic elements, namely rhythm, tempo, and so on, which can serve as conduits for emotional content for both sound (music) and visuality (the moving body).

There is a long history of Western choreographers creating dances to be performed in silence. Laban's concept of Eigenkunst, for instance, promoted choreographic works performed in silence. Mary Wigman created solos that explored specific movement themes. Monotony Whirl (1926) was seven minutes of twirling. Doris Humphrey's theory of "breath rhythm" formed the basis of her choreography in which she constructed movement phrases compatible with the rise and fall of the dancer's breath and her extensive choreographic catalogue contains several dancers performed in silence. ${ }^{20}$

While it is possible to place Sullivan and Renaud's early choreography that is performed without traditional musical accompaniment in this context, it is also useful to situate this work in the more contemporaneous context of the late 1940s avant garde musical experimentation. In so doing, Dédale and Déformité can be seen to anticipate John Cage's 4'33" (1952) as Sullivan and
19. Sullivan, [1948]1985, p. 114-115.

20. For instance, see the following choreographic works by Humphrey that were performed in silence: Sonata Tragica (1923), Water Study (1928), Life of the Bee (1929), Drama of Motion (1930). Other early and mid twentieth-century choreographic works performed in silence include the following: Helen Tamiris, The Queen Walks in the Garden (1927); David Lichine, La Création (1948); Deryk Mendel Épithalame (1958), among others. 
21. While still in New York, Sullivan also had shown the piece to Mary Anthony at the New Dance Group (Françoise Sullivan, interview with author, May 8, 1999). A handwritten note on the Récital de danse draft of the program states: "Conseillère artisique: Mary Anthony." See Récital de danse, program, Françoise Sullivan Private Papers, Montréal.

22. Françoise Sullivan, interview with author, May 6, 1999.
Renaud's breathing, the sound of their feet running and jumping, the swishing of their arms across the fabric of their skirts invite viewers to reject the notion of silence and to hear the ambient sounds generated by dancing bodies.

\section{Formative Collaborations}

In addition to thinking about how an understanding of Dédale and Déformité is enhanced by reorienting the conversation away from Automatist ideas formulated in relation to painting and instead to consider these works within the context of music, it is also important to insist that Mercure was the first composer to work with the Automatist choreographers as they created. Mercure also arranged for musicians, including himself, to perform his compositions during their dance concerts. In short, Mercure needs to be repositioned in history as a significant partner in Sullivan and Renaud's key choreographic works during the late 1940s and early 1950s. During his formative years as a composer, Mercure was not only creating for voice (Colloque, 1948), full orchestra (Kaléidoscope, 1947/1948), instrumental ensemble (Pantomime, 1949) and choir with orchestra (Ils ont détruit la ville, 1950), but also for moving bodies. As a result, his collaborations with these two choreographers arguably affected his approach to composition.

Unfortunately, the details of most of these early collaborations have been lost, but the documentary evidence that does remain allows for some fragmentary observations. In Sullivan's private papers, for instance, is a handwritten program for a "Studio Evening" dance concert slated for the spring of $194^{8}$. The final work of the evening was a theatricalization of the Edgar Allan Poe story, The Masque of the Red Death. Mercure is listed as the composer. It is not known if the performance actually took place, or if Sullivan ever choreographed the piece, though the absence of any other archival evidence suggests that the program was a blueprint for a dance concert that never occurred.

In any case, it is clear that the April 3,1948 Récital de danse that Sullivan shared with Renaud did occur and, for the last work in this dance concert, Sullivan enlisted Mercure as the composer. The work was a duet Sullivan called Dualité. It was based on a dream Sullivan had while in New York that she transposed into a dance while studying choreographic composition at the Boas studio. ${ }^{21}$ In the dream, Sullivan saw two sides of her personality embodied by two different women. ${ }^{22}$ One of the women rode a white horse and was beautiful. The other woman, astride a grey horse, was ugly. These contrasting halves are in conflict. They temporarily break free of each other, but are ultimately reunited. 
While there are unnamed characters and a narrative context for the dance, the choreography for Dualité does not venture into pantomime or overt storytelling. Instead, the dancers' spatial and kinetic relationships convey the elasticity and tension of their bond. For instance, at the beginning of the dance, the two dancers enter together. They are standing on demi-pointe back-toback and holding hands. They chaîné turn as one entity moving through space. They eventually separate and move independently of one another, but soon return to each other, mirroring each other's movements. The dance has a circular structure because the piece ends as it begins, with the dancers once more back to back, hand in hand, turning round and round off the stage.

Although the score for Dualité has not been found, it appears that Mercure set the piece to music in 1948 for the Récital de danse. ${ }^{23}$ During the performance, he accompanied the dancers on the piano and Gérard Gagnon played the trumpet. ${ }^{24}$

The planned collaboration for a theatrical version of Poe's story and the premise of Dualité arguably suggest that in the late 1940s both Sullivan and Mercure were interested in how music and movement could support narrative and characterization. If so, then once again, music helps to underscore how the Automatist tenets of spontaneity and non-figuration are not the best guides to the early works of the choreographers associated with the group.

The following year, in 1949, Sullivan shared a performance with Alexander Kerby, the young director of Theatre 6. Held at Le Théâtre des Compagnons on May $8^{\text {th }}$ and $9^{\text {th }}$, Les Deux Arts, as the evening was billed, featured three choreographic works set to music by Mercure. ${ }^{25}$ One of the works was Dualité. Unfortunately, Mercure's score for another, Lucrèce Borgia, also has not been located, though it is known that it was a fourminute composition for trumpet, piano and percussion instruments, which Sullivan and Racheed Aboud, one of her students, used to co-create the dance. ${ }^{26}$ What is also known about the music is that during the 1949 performance, Mercure played the harpsichord and the piano. Gerald Gagnier was on the trumpet and Louis Charbonneau played percussion instruments. ${ }^{27}$ Finally, the program for the concert indicates that Sullivan saw the movement potential in Mercure's Pantomime because she performed her dance La Femme archaïque to a Radio-Canada recording of the work as part of the evening's presentation. ${ }^{28}$

Although the 1986 reconstructed version of La Femme archaïque does not appear to echo the palindromatic structure of Pantomime perfectly, the choreographic work begins and ends in the same pose, which was based on a figure in a painting with same title that Sullivan had purchased from the
23. Mercure's name is included on the program for Récital de danse. In the "Catalogue chronologique des ouvres" included in Compositeurs au Québec, the listing for Dualité on page thirteen is accompanied by the note "musique de ballet d'après Kaléidoscope." The same source notes that the score is "introuvable." Similarly, for the 1986 Dance Collection Danse reconstruction, Dualité was performed in silence because Sullivan and her colleagues could not locate the score.

24. Récital de danse, program, Françoise Sullivan Private Papers, Montréal. Also, see Lyse Richer-Lortie, 1975, p. 152-155.

25. Les Deux Arts, program, Françoise Sullivan Portfolio, Dance Collection Danse Archives, Toronto.

26. Richer-Lortie, 1975, p. 154. Also see the chronology of Mercure's work in Compositeurs au Québec. As with Dualité, the note for Lucrèce (called Lucrèce Borgia in the chronology) is “introuvable." See Laplante, 1976, p. 14. 27. Les Deux Arts, program, Françoise Sullivan Portfolio, Dance Collection Danse Archives, Toronto.

28. The 1986 Dance Collection Danse reconstruction of Femme archaïque, which is available on video, was set to Mercure's Kaléidoscope, not Pantomime. As viewers will note, Sullivan has opted to use the opening few minutes of Kaléidoscope to accompany her reconstructed choreography. Interestingly, all performances of Femme archaïque since the 1986 Dance Collection Danse reconstruction have been performed to Kaléidoscope. 
29. For an in-depth analysis of Pantomime's structure, see Stein, 2007. For a discussion of La Femme archaïque, see Lindgren, 2003, p. 93.

30. Sullivan as quoted in Hill, 1988.

31. Françoise Sullivan, c. 1985

32. As I have written elsewhere: "While the work's genesis is in a painting, its movement dynamics, which teeter between apparent abandon and control, ecstasy and complete restraint, resonate on a primal level. This is a dance about the visceral contrasted with the refined - the so-called primitive co-existing with the contemporary." See Lindgren, 2003, p. 93.

33. Whitehead, 1949, p. 6

34. Vincent, 1949

35. Paul Roussel in Gagnon, 1998, p. 612. Roussel was a writer and critic in Montréal. In addition to Le Canada, Roussel also contributed articles to L'Autorité and Notre Temps. He later joined the CBC as the editor of $L a$ Semaine à Radio-Canada and produced programs, including "Vienne la nuit". For more information about Roussel, see "Paul Roussel" in Encyclopedia of Music in Canada, accessed April 5, 2011 [www.thecanadianencyclopedia.com/ index.cfm?PgNm=TCE\&Params=U1A RTU0003041]

36. "La critique dit...", in Gagnon, 1998, p. 613 .
Automatist painter, Jean-Paul Mousseau. ${ }^{29}$ In the choreographic work, the dancer starts and finishes the work facing the audience. Her feet in parallel first with her arms bent at the elbows. Her left hand extends across her pelvis and her right arm is in the same position, but behind her back. At the time, Sullivan was also very interested in mythology and she later interpreted La Femme archaïque as having a "mythic quality." $3^{\circ}$ More specifically, according to Sullivan, the piece was about "women before historical times." ${ }^{31}$ The stasis of the opening and closing pose was in contrast to the energy of the movement, which ranged from the dancer's frenzied twirling, hopping on the down beat and the shaking of her torso and arms, to moments of fluid control as the dancer traced serpentine shapes through the air with her hands and hips. ${ }^{32}$

The collaboration between Sullivan and Mercure helped to foster a public dialogue about new music and modern dance. In this way, the critical response constitutes a historical record of aesthetic attitudes in circulation in Montréal during the late 1940s. As Harold Whitehead, the reviewer for The Montreal Gazette reported, the audience reacted warmly to Sullivan: "Miss Sullivan has a charming stage personality and is an easy, relaxed dancer, and from the amount of hand-clipping [sic] and enthusiastic shouts of 'Bravo' which greeted her every appearance on the stage, she has a very large following in the city." 33 Not all reviewers felt the audience's adoration of Sullivan was fully warranted. One reviewer confessed that he was perplexed by Sullivan's intricate hand movements in La Femme archaïque that involved turned out palms and reminded him of classical Indian choreography, but which he felt were out of place in a modern dance work. ${ }^{34}$

Paul Roussel, writing for Le Canada, generally liked Sullivan's choreography, but - despite the structural similarities - felt that La Femme archaïque was not well suited to Mercure's music: "Les rythmes enlevants établis par la Pantomime pour quatorze instruments à vent et timbales de Pierre Mercure imposent un mouvement impérieux auquel Françoise Sullivan veut échapper. Il résulte de cette évasion fâcheuse un manque de logique et d'unité qui affaiblit l'intérêt." 35

An unnamed writer for Le Petit Journal conversely felt that Sullivan and Mercure were artistically compatible: "Dans Dualité, Lucrèce et Femme archaïque, la jeune artiste montréalaise a manifesté une souplesse, une spontanéite d'émotion extraordinaires, tirant profit de l'excellente musique de Pierre Mercure." ${ }^{6}$

Mercure's work with Sullivan in 1949 arguably helped to raise his profile as an artist conversant in more than one aesthetic discipline with the press 
and the adventurous dance audiences in Montréal attracted to Sullivan's choreography. The critical responses also show that Mercure's compositions for Les Deux Arts were considered to be one of the highlights of the concert. Roussel was generally enthusiastic and complimentary in his comments about Mercure's music as a young composer with much potential:

Nous avons déjà apprécié les dons indéniables de Pierre Mercure. Il a de l'invention, du goût, de l'intelligence et surtout, beaucoup d'ambition. Une tendance à vouloir faire des bouchées doubles devra, pour parvenir au succès complet, être retenue et maîtrisée. Mercure propose, très jeune, un métier en passe de s'affiner, une imagination un peu facile, parfois, doublée d'une musicalité intéressante. Qu'il prenne garde de se répéter et qu'il veille, parfois, un peu plus soigneusement aux formes, et il deviendra bientôt un compositeur digne de notre entière admiration. ${ }^{37}$

Another reviewer deemed Mercure's music to be "vraiment intéressante" ${ }^{146}$. Jean Vincent, who reviewed the evening for Le Devoir, went further in his praise of Mercure's contribution to the evening: "Il faut rendre hommage également à M. Pierre Mercure qui a composé presque tout l'accompagnement musical, lequel forme le plus substantiel morceau du programme." $3^{8}$

The comments of the critics collectively suggest that the evening should have been called Les Trois Arts and also indicate their openness to interdisciplinary collaborations. Even if the critics did not like everything they saw and heard, their reviews demonstrate that they took Sullivan's choreography and Mercure's music seriously.

Mercure's participation in the 1948 and 1949 concerts also need to be examined for their impact on the composer's subsequent work. As Lyse Richer-Lortie has suggested, Mercure's collaboration with Sullivan "shows the first indication of a continuing preoccupation, the integration of different creative forms, fusing theatre, music, painting and the dance. This need was undoubtedly encouraged by [the Automatists]." 39 Certainly, throughout the rest of his career, his innovative and successful interdisciplinary collaborations defined his approach as the music director of Renaud and Françoise Riopelle's performance ensemble, Le Groupe de danse moderne de Montréal, which existed from 1960 to $1965.4^{\circ}$ Mercure was equally engaged in interdisciplinary collaboration in his work as a producer for CBC Radio Canada television programs, including for "L'Heure du Concert", as well as in his monumental undertaking in organizing the Semaine internationale de musique actuelle in 1961, which not only featured many of the most important avant garde composers such as Karlheinz Stockhausen and John Cage, but introduced Montréal audiences and the local dance community to the cognate choreographic experiments of Cage's partner, Merce
37. Paul Roussel in Gagnon, 1998, p. 612

38. Vincent, 1949

39. Richer-Lortie, 1975, p. 152. For similar statements, also see Keillor, 2006, p. 223; and Lefebvre, 2001, p. 1151.

40. "Le Groupe de danse moderne de Montréal," program, February 1964, Jeanne Renaud Private Papers, Montréal. Also see Ellenwood, 1992, p. 308. 
41. Roberts, 1969, p. 205.

42. Gagnon, 1998, p. 472.

43. Récital de danse, program, March 3, 1950, Jeanne Renaud Private Papers, Montréal. Renaud had moved to Paris in December 1948 with her husband, a psychiatrist, so he could study with Jacques Lacan. After the excitement of dance explorations in New York, Renaud found Paris to be a disappointment. Nevertheless, she continued to work on her choreography. Her most important dance of the period is L'Emprise, which she had begun during her time in New York. Déformité was one of the other pieces that Renaud performed, though she had renamed the work Nuit infernale.
Cunningham, and Cunningham's New York dance colleagues, Alwin Nikolais and James Waring. ${ }^{41}$

\section{Aleatoric Experimentation}

The luxury of working with a live composer in the 1948 and 1949 concerts meant that - with the exception of Mercure's Kaleidoscope for Dualité and Pantomime for La Femme archaïque - Sullivan did not shape her choreography to fit pre-existing compositions, a practice that was a necessity for most choreographers. ${ }^{42}$ Mercure usually collaborated with Sullivan by watching the choreography as it was created in the studio and then composing the music later in private. This may be how they worked for Lucrèce Borgia, and, later with Renaud for L'Emprise (1950). His compositions, however, were not secondary to the movement. There was no hierarchical relationship between the aural and the corporeal. The parity and mutual independence of art forms was particularly in evidence in Mercure's working method when he collaborated with Renaud on her choreographic work L'Emprise in Paris for a 1950 concert organized at the American Students' and Artists' Center on the Boulevard Raspail. 43

The 1986 reconstructed version of L'Emprise begins with the dancer walking lethargically on the beat onto the stage. She picks up a large rope circle on the stage, steps inside and wraps it around her waist. As she walks forward she raises the rope taut in front of her until she is holding it near the top of her head. When she pliés, she lowers the rope back to shoulder height until she suddenly snaps the rope back against her neck as if someone had grabbed it and was trying to choke her. The dancer runs, pirouettes and pivots around the stage with the rope still pressed against her neck. The flattened plane of her body is emphasized as she frantically pivots around like a playing card on its edge. By wrapping the rope again so that it is behind her, the dancer must extend her arms back. She jerks from side to side across the stage as if caught between two people grabbing at her elbows. As she spins in tight circles with her arms rising upwards, the rope falls from her waist and onto the floor. The dancer steps out of the ring of rope and backs away. Even when free and performing larger, unfettered movements, the dancer cannot seem to escape the rope as her attention always gravitates back to it. As the title of the work indicates, the dancer appears to be under the rope's control. When she can resist it no longer, the dancer returns to the rope and wraps it around her neck like a noose. Although it is unclear what the rope symbolizes, its negative allure unequivocally entices yet stifles the dancer. At the end of the dance, when the dancer tenderly places the rope over one shoulder and - with each step she takes as she slowly walks 
off the stage - draws the rope down the front of her body. The effect is enigmatic and disquieting. Has she conquered or capitulated?

Mercure was in Paris as a student of Nadia Boulanger, but because his interests were increasingly oriented towards new music he soon struck out on his own to explore aleatoric music, musique concrète, improvisation, superimposed forms, and collective collaborations. ${ }^{44}$ As he later told one interviewer about his time in Paris: "Musique concrète along with chance music appealed to me immensely. Gabriel Charpentier [another composer from Quebec] and I would spend hours experimenting with chance compositions and improvisations. For instance, we would each write on half of a two-piano composition with a vaguely given form and timing. Each would write his own part independently. Then we would meet the next day and play this music together, thrilled by the fantastic effects of our experiment." 45

Renaud was aware that Cunningham and Cage were in Paris during the summer of 1949, and admired the freedom that each of their disciplines had when the two men worked together. As she later stated, the autonomy of the arts in the Cunningham-Cage collaborations reminded her of the freedom experienced by the Automatists. Nevertheless, the choreographer seems to have been less comfortable with the element of chance infused into her own work by Mercure:

À mon ami Pierre Mercure qui était venu étudier à Paris avec Nadia Boulanger, je demandai d'écrire la musique pour ce spectacle - ce qu'il avait déjà fait pour mes spectacles antérieurs à Montréal. Il accepta avec plaisir et mit à contribution femme et amis : c'est Monique Mercure qui était au violoncelle, Gabriel Charpentier au piano, Mercure au basson et Jérôme Rosen à la clarinette. [...]

En réalité l'aléatoire régnait : j'allais aux répétitions chez Mercure et, à ma grande surprise, la musique était chaque fois différente et jusqu'à la dernière minute, je ne savais trop ce qui serait joué lors du spectacle. Mercure avait quelques repères à certains endroits des chorégraphies, sans plus. [...] Ma patience était mise à rude épreuve. $4^{46}$

As Renaud recalls, Mercure's music for L'Emprise had a basic set structure, but the musicians had latitude to improvise throughout the piece. ${ }^{47}$ Although it is clear that chance was part of the performance, whether Mercure was deliberately playing with the idea of chance while he wrote the music for Renaud's concert is unknown. If so, Renaud was an unwitting collaborator in the game. Whatever Mercure's motivation, it is possible to view the concert not only as a transnational demonstration of Automatist spontaneity, but also as the kind of chance experimentation that was reverberating through the communities of avant garde musicians at the time. $4^{8}$
44. Richer-Lortie, 1975, p. 152

45. Mercure in CBC International, 1964, p. 63.

46. Jeanne Renaud in Gauvin, 2000, p. 191. An English translation appears in Lindgren and Ellenwood, 2009. For similar comments, see Gagnon, 1998, p. 648-649. More generally, see Viau, 1998, p. 46 (an English translation of the Viau text is found in the same volume on p. 118).

Renaud's anxiety had also been heightened by Jean-Paul Riopelle who had agreed to create the sets for the performance, but continually deflected Renaud's queries about their status as the date of the dance concert approached. Part of his evasiveness was due the fact that the poor equipment available to him limited the creative possibilities. However, according to Renaud, in the end, Riopelle was able to find a very creative solution:

Avec une lanterne magique que nous avions louée, il projeta en guise de décor des diapositives sur lesquelles il avait peint, mais il trouva l'effet trop statique. S'arrachant quelques cheveux, il les lança sur les diapositives: au contact de la chaleur de la lampe, elles fondaient et les cheveux bougeaient. L'effet était dynamique et j'étais émerveillée du résultat. Je me demandais s'il était encore nécessaire que je danse: Riopelle rétorqua que le décor était là parce que je dansais! Pour une des danses, il avait choisi une ouvre de De Chirico que représentait un large espace: j'avais en effet besoin d'une perspective beaucoup plus grande que celle de la scène du théâtre. Riopelle trouvait des solutions pour tout, son imagination était exceptionnelle.

For further details, see Renaud as quoted in Gauvin, 2000, p. 191-192. An English translation appears in Lindgren and Ellenwood, 2009.

47. Jeanne Renaud, telephone interview, October 30, 2010.

48. For instance, see Cunningham, 1982, p. 107-108. Also see Nicholls, 2007, p. 42. 
In the 1950s, Sullivan gravitated to dance and visual art before reincorporating experimental dance into her creative projects in the 1970s. Renaud eventually abandoned her earlier interest in emotion and instead begin to focus on formalist choreography. Her work, Polarité (1964), which she set to Piano Sonata $n^{\circ} 1$ by Pierre Boulez, arguably marked her move towards the minimalist and intellectual performance style that defined her choreographic works for Le Groupe de la Place Royale, the company she founded in 1966, the same year Mercure died.

Although all three artists moved beyond the ideas they explored in Renaud and Sullivan's dance concerts of 1948, 1949 and 1950, their early experimentations and collaborations augment our understanding of the Automatists because they prompt a rethinking of the parameters of Automatist interdisciplinarity and provide an opportunity to validate the presence and importance of music within the group's history.

\section{B IB LIOGRAPHY}

Betтis, Valerie (1979), interview with Wendy Laakso, Oral History Project, Dance Collection, New York Public Library of the Performing Arts, New York, May 10, p. 53.

Bourassa André-G. and Lapointe, Gilles (1988), Refus global et ses environs, 1948-1988, Montréal, l’Hexagone.

CbC international Service (1964), Thirty-Four Biographies of Canadian Composers, Montréal, n.p.

Cunningham, Merce (1983), “A Collaborative Process between Music and Dance," in A John Cage Reader, Peter Gena, Jonathan Brent and Don Gillespie (ed.), New York, CF Peters Corp, p. 107-108.

Ellenwood, Ray (2006) “Jeanne Renaud in Her Own Time," Dance Collection Danse, nº 62, p. 16-22.

EllenwoOD, Ray (1987), “The Automatist Movement of Montreal: Towards Non-Figuration in Painting, Dance, and Poetry," Canadian Literature, 113-114, p. 11-27.

Ellenwood, Ray (1992), Egregore: A History of the Montréal Automatist Movement, Toronto, Exile.

ELlEnwOOD, Ray ([1985] 2009), introduction to Total Refusal, Refus global: The Complete 1948 Manifesto of the Montreal Automatists, Holstein, Exile.

Gagnon, François-Marc (1998), Chronique du mouvement automatiste québécois, 1941-1954, Outremont, Lanctôt.

Gauvin, Lise (dir.) (2000), Les automatistes à Paris, Montréal, Les 400 coups.

Gosselin, Claude (1981), "Sur Françoise Sullivan”, in Françoise Sullivan Rétrospective, Montréal, Ministère des Affaires culturelles, p. 14 .

Hill, Heather (1988), "Daring Refus Global Dance Reborn,” The Montreal Gazette, April 29.

KeILlor, Elaine (2006) Music in Canada: Capturing Landscape and Diversity, Montréal and Kingston, McGill-Queen's University Press.

Laplante, Louise (ed.) (1976), Compositeurs au Québec. Pierre Mercure, Montréal, Centre de musique canadienne. 
Lapointe, Gilles (2009), La comète automatiste, Montréal, Fides.

LE vicomte (1949), "Françoise Sullivan, qui aime toujours la peinture, montre également une prédilection pour les bonbons," PM Journal, mai 26, p. 45.

Lefebvre, Diane and Richer-Lortie Lyse (1976), "Face à l'automatisme," in Compositeurs au Québec. Pierre Mercure, Lise Laplante (ed.), Montréal, Centre de musique canadienne, p. 11.

Lefebvre, Marie-Therese (2001), "Overview of Quebec," in Garland Encyclopedia of World Music, vol. 3, New York, Garland, p. 1151.

Lindgren, Allana C. (2005), "Infinite Originality: The Artistry of Françoise Sullivan Web Exhibition,” Toronto, Dance Collection Danse Archives. [Open Access Publication: www. dcd.ca/exhibitions]

Lindgren, Allana C. and ElLENwood Ray (2009), "Jeanne Renaud: Interdisciplinary Innovations Web Exhibition," Toronto, Dance Collection Danse Archives. [Open Access Publication: www.dcd.ca/exhibitions].

Lindgren, Allana C. (2003), From Automatism to Modern Dance: Françoise Sullivan with Franziska Boas in New York, Toronto, Dance Collection Danse Press/es.

NASGAard, Roald and Ellenwood Ray (2009), The Automatiste Revolution: Montreal 1941-1960, Vancouver, Toronto, Berkeley, Douglas \& McIntyre; The Varley Art Gallery of Markham.

Nicholls, David (2007), John Cage, Urbana and Chicago, University of Illinois Press.

Nyman, Michael (1974), Experimental Music: Cage and Beyond, New York, Schirmer Books.

Perron, Maurice (1999), Maurice Perron: Photographies, Québec, Musée du Québec.

Richer-Lortie, Lyse (1975), "Pierre Mercure," in Contemporary Canadian Composers, Keith MacMillan and John Beckwith (ed.), Toronto, Oxford University Press, p. 152-155.

Robert, Guy (1973), L’Art au Québec depuis 1940, Montréal, La Presse.

Roberts, John (1969), "Communications Media," in Aspects of Music in Canada, Arnold Walter (ed.), Toronto, University of Toronto Press, p. 205.

Smart, Patricia (1998), Les femmes du Refus global, Montréal, Boréal.

STEIN, Edward Garret (2007), "An Examination of Major Works for Wind Band and Chamber Ensemble: "Pantomime" by Pierre Mercure, "From Chaos to the Birth of a Dancing Star" by Allan Gordon Bell, and “Tafelmusik” by Godfrey Ridout”, MA thesis, Kansas State University.

Sullivan, Françoise ([1948]1985), "Dance and hope," in Refus global: The Complete 1948 Manifesto of the Montreal Automatists, Paul-Émile Borduas, et al. (ed.), Ray Ellwood (trans.), Toronto, Exile, p. 114-115.

Sullivan, Françoise (c. 1985), "Rhythms of an Era", reconstruction form, Françoise Sullivan Fonds, Dance Collection Danse Archives, Toronto.

VIAU, René (1998), "Des automatistes à Paris", in Refus global (1948): le manifeste du movement automatiste/Manifesto of the Automatist Movement, Paris, Services culturels de l'Ambassade du Canada, p. 46.

Vigneault, Louise (2002), Identité et modernité dans l'art au Québec: Borduas, Sullivan, Riopelle, Montréal, Hurtubise HMH

Vincent, Jean (1949), “Les Deux Arts," Le Devoir, May 9.

Whitehead, Harold (1949), "Dance Program Proves Success,” The Montreal Gazette, May 10, p. 6. 